\title{
Postnatal changes in ghrelin mRNA expression and in ghrelin-producing cells in the rat stomach
}

\author{
I Sakata, T Tanaka ${ }^{1}$, M Matsubara, M Yamazaki, S Tani ${ }^{1}$, \\ $\mathrm{Y} \mathrm{Hayashi}^{2}$, K Kangawa ${ }^{3}$ and T Sakai \\ Department of Regulation Biology, Faculty of Science, Saitama University, 255 Shimo-ohkubo, Saitama, Saitama 338-8570, Japan \\ ${ }^{1}$ Faculty of Pharmaceutical Sciences, Josai University, 1-1 Keyaki-dai, Sakado, Saitama 350-0295, Japan \\ ${ }^{2}$ Suntory Institute of Medicine Research Development, 2716-1 Kurakake, Akaiwa, Chiyoda, Gunma 370-0503, Japan \\ ${ }^{3}$ Department of Biochemistry, National Cardiovascular Center Research Institute, Suita, Osaka 565-8565, Japan \\ (Requests for offprints should be addressed to T Sakai; Email: tsakai@seitai.saitama-u.ac.jp) \\ (I Sakata and T Tanaka contributed equally to this work)
}

\begin{abstract}
Ghrelin was recently isolated from the rat stomach as an endogenous ligand for the GH secretagogue receptor. Although it is well known that a large amount of ghrelin is produced in the gastrointestinal tract, developmental changes in ghrelin mRNA expression and differentiation of ghrelin-immunopositive (ghrelin-ip) and mRNAexpressing (ghrelin-ex) cells in the stomach have not been elucidated.

In this study, we therefore investigated the changes in ghrelin mRNA expression levels and in the numbers of ghrelin-ip and -ex cells in the stomachs of 1- to 8 -week-old male and female rats by Northern blot analysis, immunohistochemistry and in situ hybridization. Northern blot analysis showed that the level of weak ghrelin mRNA expression was low in the postnatal period but then increased in a dimorphic pattern, i.e. transient stagnation at 4 weeks in the male rats and at 5 weeks in the
\end{abstract}

female rats. The number of ghrelin-ip and ghrelin-ex cells also increased after birth, and more numerous ghrelin cells were found in female rats than in male rats, and this finding was confirmed by Northern blot analysis. Ghrelin-ip and -ex cells first appeared in the glandular base of the fundic gland and then they were found in the glandular base and the glandular neck at 3 weeks of age, suggesting that the distribution of ghrelin cells is extended from the glandular base to the glandular neck during the postneonatal development period. This is the first report on detailed changes in postneonatal ghrelin expression level and in the number of ghrelin cells in the rat stomach. The sexual dimorphism of ghrelin expression and ghrelin cell differentiation suggest that ghrelin plays an important physiological role in the stomach.

Journal of Endocrinology (2002) 174, 463-471

\section{Introduction}

Ghrelin was recently isolated from the rat stomach as a endogenous ligand for the growth hormone secretagogue receptor (GHS-R) and was found to consist of 28 amino acids, in which the third serine residue is $n$-octanoylated (Kojima et al. 1999). Ghrelin has been shown to regulate not only growth hormone $(\mathrm{GH})$ release from the pituitary gland in vivo and in vitro (Kojima et al. 1999, Date et al. 2000, Seoane et al. 2000, Yamazaki et al. 2002) but also to have various physiological functions, such as food intake, gastric acid secretion and gastric motor activity (Masuda et al. 2000, Wren et al. 2000, Date et al. 2001, Nakazato et al. 2001). It has been reported that ghrelin produced in the stomach is a major source of plasma ghrelin (Ariyasu et al. 2001) and that ghrelin in the stomach may play an important role, either directly or indirectly, in these functions (Asakawa et al. 2001a, Inui 2001). Rat ghrelin cells were found to be localized in the mucosa of the stomach, duodenum, ileum, cecum and colon but not in the myenteric plexus, and they can be classified into open- and closed-type cells. The largest number of ghrelin cells was found in the stomach (Sakata et al. 2002). It has also been reported that ghrelin and 27 amino acid des-Gln(14)-ghrelin (Hosoda et al. 2000b) exist as two molecular forms in the stomach, i.e. $n$-octanoyl ghrelin, a physiologically active form, and des-n-octanoyl ghrelin, an inactive form (Hosoda et al. 2000a), and that ghrelin mRNA in the stomach increases during fasting (Toshinai et al. 2001) and stress (Asakawa et al. 2001b).

GH secretory patterns change during development in both male and female rats, and GH secretion clearly shows a sexually dimorphic peak at the onset of puberty (Eden 1979). Although it has been reported that GH-releasing 
hormone (GHRH) and somatostatin (SRIF) mRNA levels show age-dependent changes and sexual dimorphism (Argente et al. 1991), the developmental GH secretory pattern cannot be explained only by these neuropeptides. Meanwhile, the ghrelin gene has been reported in the pituitary gland and is highest in the fetus and declines during the postembryonic period, and pituitary GHS-R mRNA expression level has been found to fluctuate with increasing age in young rats (up to 70 days) (Kamegai et al. 1999), suggesting that pituitary ghrelin is an important hormone for weaning, body growth or onset of puberty during neonatal and postneonatal periods.

On the other hand, it is thought that ghrelin produced in the stomach is the major source of circulating ghrelin (Ariyasu et al. 2001) and this plasma ghrelin also may exert a powerful influence on the development of the rat. It is thus important to clarify the developmental expression of ghrelin mRNA and the differentiation of ghrelin cells in the stomach. In this study, we therefore investigated the developmental change in ghrelin in the stomach of male and female rats by Northern blot analysis, immunohistochemistry (IHC) and in situ hybridization (ISH).

\section{Materials and Methods}

\section{Animals}

Male and female Wistar rats (1- 8 weeks of age) were purchased from Japan Laboratory Animals, Inc. (Tokyo, Japan) and were housed under controlled conditions (temperature of $23^{\circ} \mathrm{C}$ and light from 0800 to $2000 \mathrm{~h}$ ). The rats were also provided with standard rat chow and water ad libitum. All procedures used in this study were performed in accordance with institutional guidelines for animal care at Saitama University.

\section{Tissue preparations}

Animals were deeply anesthetized with sodium pentobarbital $(50 \mathrm{mg} / \mathrm{kg}$ i.p.) and perfused first with $10 \mathrm{mM}$ PBS, $\mathrm{pH} 7 \cdot 5$, and then with $4 \%$ paraformaldehyde in $50 \mathrm{mM}$ phosphate buffer (PB), $\mathrm{pH} 7 \cdot 4$. Segments of the stomach, approximately $1 \mathrm{~cm}$ in length, were quickly removed and opened along their longitudinal axes. The tissue blocks were dehydrated with an ascending ethanol series and immersed in xylene and then embedded in Paraplast (Oxford Labware, MO, USA). Serial sections ( $6 \mu \mathrm{m}$ thick) were made and mounted on silane (ShinEtsu Chemicals, Tokyo, Japan)-coated slides.

\section{Immunohistochemistry}

Immunohistochemical detection of ghrelin cells using rabbit anti-ghrelin serum (no. 603) was carried out by the avidin-biodin-peroxidase complex (ABC) method. The production and specificity of the anti-ghrelin serum used in this study have been reported previously (Kojima et al. 1999), and this antiserum recognizes the $n$-octanoylated side chain of the N-terminal region of ghrelin (Date et al. 2000, Hosoda et al. 2000a). Immunohistochemical staining was performed basically according to the previously reported procedure (Sakai et al. 1994). Briefly, the sections were deparaffinized with xylene and rehydrated through descending concentrations of ethanol. Next, the sections were treated with $0.5 \%$ sodium metaperiodate to block endogenous peroxidase for $15 \mathrm{~min}$ at room temperature and then incubated with $1 \%$ normal horse serum and $0.4 \%$ Triton X-100 in PBS for $1 \mathrm{~h}$. After washing with PBS for $15 \mathrm{~min}$, the sections were incubated with anti-ghrelin serum diluted 1:150000 in PBS for $15 \mathrm{~h}$ in a humid chamber. After washing with PBS, a second incubation with biotin-conjugated anti-rabbit IgG serum (Vectastain ABC kit; Vector, Burlingame, CA, USA), diluted 1:300 with PBS, was carried out for $1 \mathrm{~h}$, and this was followed by further washing with PBS. Finally, the sections were incubated for $30 \mathrm{~min}$ with an avidin-biodin-peroxidase complex (Vectastain ABC kit) prepared according to the manufacturer's instructions. After washing with PBS for $15 \mathrm{~min}$, the sections were reacted in $0.02 \% 3,3-$ diaminobenzidine-tetrachloride mixed with $0.006 \%$ $\mathrm{H}_{2} \mathrm{O}_{2}$ in $0.05 \mathrm{M}$ Tris $-\mathrm{HCl}, \mathrm{pH} 7 \cdot 6$, for $1-3$ min to detect immunostaining. After washing with distilled water, the sections were dehydrated with a graded ethanol series, cleared in xylene, mounted with Entellan (Merck, Darmstadt, Germany), and viewed under a light microscope (BX60; Olympus, Tokyo, Japan). All the incubations were carried out in a humidity chamber at room temperature.

\section{In situ hybridization}

The sections were deparaffinized with xylene, rehydrated through descending concentrations of ethanol, and washed in diethylpyrocarbonate (DEPC)-treated PBS for $15 \mathrm{~s}$ twice. Next, the sections were washed in DEPC-treated PBS, treated with $8.0 \mu \mathrm{g} / \mathrm{ml}$ proteinase $\mathrm{K}$ for $30 \mathrm{~min}$ at $37^{\circ} \mathrm{C}$, and fixed with $4 \%$ paraformaldehyde in $50 \mathrm{mM}$

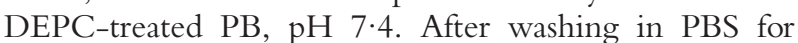
$1 \mathrm{~min}$, the sections were incubated with $0 \cdot 2 \mathrm{M} \mathrm{HCl}$ in DEPC water and then washed in PBS for $1 \mathrm{~min}$. The sections were treated with $0 \cdot 1 \mathrm{M}$ triethanolamine- $\mathrm{HCl}$, $\mathrm{pH} 8 \cdot 0$, for $1 \mathrm{~min}$ and $0.25 \%$ acetic anhydride in $0.1 \mathrm{M}$ triethanolamine for $10 \mathrm{~min}$, washed in PBS for $1 \mathrm{~min}$, and then immersed in a graded ethanol series (70, 80 and 90\%) for $15 \mathrm{~s}$ each. Next, the sections were treated with 100\% ethanol for $15 \mathrm{~s}$ twice and dried for $20 \mathrm{~min}$. Finally, $2 \mathrm{ng} / \mu \mathrm{l}$ Digoxigenin (DIG)-labeled anti-sense and sense RNA probes (position 112-458; GenBank no. AB029433), synthesized from stomach cDNA using a labeling kit (Boehringer Mannheim GmbH, Mannheim, 
Germany), were diluted in hybridization buffer and dropped onto the tissue sections. The sense RNA probe was used as negative control. The sections were covered with Parafilm (American Can Company, CT, USA) and incubated for $16 \mathrm{~h}$ at $42{ }^{\circ} \mathrm{C}$ in a humidity chamber. The covers were removed by soaking the slides in $5 \times$ SSC and immersed in $2 \times$ SSC containing $50 \%$ formamide for $30 \mathrm{~min}$. The sections were then treated with TNE (10 mM Tris-HCl, pH 7.6, $500 \mathrm{mM} \mathrm{NaCl}, 1 \mathrm{mM}$ EDTA, pH 8.0) for $10 \mathrm{~min}$ and next with RNase A $\left(50 \mu \mathrm{g} / \mathrm{ml}\right.$ in TNE) for $30 \mathrm{~min}$ at $37^{\circ} \mathrm{C}$. The sections were immersed in TNE for $10 \mathrm{~min}$ at $37^{\circ} \mathrm{C}$ and washed with $2 \times$ SSC for $20 \mathrm{~min}$ at $55^{\circ} \mathrm{C}$ and then with $0.2 \times$ SSC for $20 \mathrm{~min}$, twice each. The sections were incubated for $5 \mathrm{~min}$ in buffer-1 $(100 \mathrm{mM}$ Tris- $\mathrm{HCl}, \mathrm{pH}$ $7 \cdot 5,150 \mathrm{mM} \mathrm{NaCl}, 0 \cdot 01 \%$ Tween 20 ), immersed in $1 \cdot 5 \%$ blocking reagent (Boehringer Mannheim $\mathrm{GmbH}$ ) in buffer- 1 for $1 \mathrm{~h}$ at $37^{\circ} \mathrm{C}$, and then washed in buffer- 1 for $5 \mathrm{~min}$. After washing, the sections were incubated with an alkaline phosphatase-conjugated anti-DIG antibody (Roche Diagnostics Corporation, Indianapolis, IN, USA) diluted 1:2000 in buffer-1. The sections were washed in buffer-1 for $15 \mathrm{~min}$ twice and in buffer-2 (100 mM Tris- $\mathrm{HCl}, \mathrm{pH}$ 9.5, $\left.100 \mathrm{mM} \mathrm{NaCl}, 50 \mathrm{mM} \mathrm{MgCl}_{2}\right)$ for $3 \mathrm{~min}$. A chromagen solution $(337 \mu \mathrm{g} / \mathrm{ml} 4-$ Nitroblue tetrazolium chloride, $175 \mu \mathrm{g} / \mathrm{ml}$ 5-Bromo-4-chloro-3indoyl-phosphate in buffer-2) was added, and the sections were incubated until a visible signal was detected. The reaction was stopped by adding a reaction stop solution (10 mM Tris-HCl, pH 7·6, 1 mM EDTA, pH 8.0), and the sections were immersed in $4 \%$ paraformaldehyde in 0.05 M PB for $120 \mathrm{~min}$. The sections were then washed with distilled water, dehydrated with a methanol series, cleared in xylene, mounted with Entellan, and viewed under a light microscope (BX60).

\section{Northern blot analysis}

Total RNA was extracted from the stomach body by the acid guanidium thiocyanate-phenol-chloroform method. Electrophoresis of $10 \mu \mathrm{g}$ total RNA was carried out in $1.0 \%$ agarose formalin gel. RNA in the gel was transferred onto a sheet of nylon membrane (Gene Screen; NEN, Boston, MA, USA) by capillary action. The membrane was prehybridized for $1 \mathrm{~h}$ at $65^{\circ} \mathrm{C}$ in a hybridizaton buffer. After hybridization for $16 \mathrm{~h}$ at $65{ }^{\circ} \mathrm{C}$ with $1 \mathrm{ng} / \mu \mathrm{l}$ of an antisense DIG-labeled rat ghrelin cRNA probe, the same probe as that used in ISH, and $1 \mathrm{ng} / \mu \mathrm{l}$ of an antisense DIG-labeled glyceraldehyde 3-phosphatase dehydrogenase (GAPDH) RNA probe (position 242-679; GenBank no. NM 017008), the membrane was washed twice with $0 \cdot 1 \%$ SDS in $2 \times$ SSC $(1 \times$ SSC: $16.6 \mathrm{mM}$ sodium chloride, $16 \mathrm{mM}$ sodium citrate) buffer at room temperature for $5 \mathrm{~min}$ and immersed twice in $0 \cdot 1 \%$ SDS in $0.2 \times$ SSC buffer at $65^{\circ} \mathrm{C}$ for $15 \mathrm{~min}$. The membrane was incubated in $1.5 \%$ blocking reagent in buffer-1 for
$30 \mathrm{~min}$ at $37^{\circ} \mathrm{C}$. After washing, the membrane was incubated with an alkaline phosphatase-conjugated antiDIG antibody (Roche Diagnostics Corporation) diluted 1:10 000 in buffer-1. A chemiluminescent assay was used to visualize the probe-target hybrids. The membrane was washed in buffer- 1 for 15 min twice and then in detection buffer $(100 \mathrm{mM}$ Tris-HCl, pH 9.5, $100 \mathrm{mM} \mathrm{NaCl})$ for $5 \mathrm{~min}$. The membrane was placed inside a plastic sheet and CDP-star (Roche Diagnostics Corporation, Indianapolis, USA) was applied and incubated for $5 \mathrm{~min}$. Finally, the membrane in the sealed envelope was exposed to X-ray film (Eastman Kodak Company, Rochester, NY, USA). After exposing, the X-ray films were developed with Kodak developer D-19 (Eastman Kodak Company), and the signals obtained were analyzed using Scion Image software (Scion Corporation, MD, USA). In the analysis, values were nomalized by the amount of GAPDH mRNA.

\section{Morphometric analysis}

The densities of ghrelin cells in the stomach were estimated. After taking digital photographs under a light microscope (BX60) with a digital camera (Coolpix950; Nikon), the number of ghrelin cells in each section was counted and the area of the mucosal layer in each section was measured using a computerized image analysis program, Scion Image. The ghrelin cell density was calculated as the number of immunopositive mucosal cells per unit area. All the data are expressed as means \pm s.E.

\section{Results}

\section{Northern blot analysis}

Ghrelin mRNA expressions in the stomach body were detected just after birth in both male and female rats, and then expression levels gradually increased with transient stagnation until 4 weeks of age in the male rats (Fig. 1A) and until 5 weeks of age in the female rats (Fig. 1B). The largest increase (about 200\%) in ghrelin mRNA in the stomach was found between 1 and 2 weeks of age in both sexes. In the male rats, the stomach ghrelin mRNA level was highest at 8 weeks of age (Fig. 1A) but, in the female rats, the highest level was found at 7 weeks of age, and the mRNA level had significantly declined at 8 weeks of age (Fig. 1B).

\section{Distribution of ghrelin-immunopositive and ghrelin $m R N A$-expressing cells}

Ghrelin-immunopositive cells (ghrelin-ip cells) and ghrelin mRNA-expressing cells (ghrelin-ex cells) were observed to be closed-type cells as previously reported (Sakata et al. 2002) (Fig. 2), and these cells showed the 
A
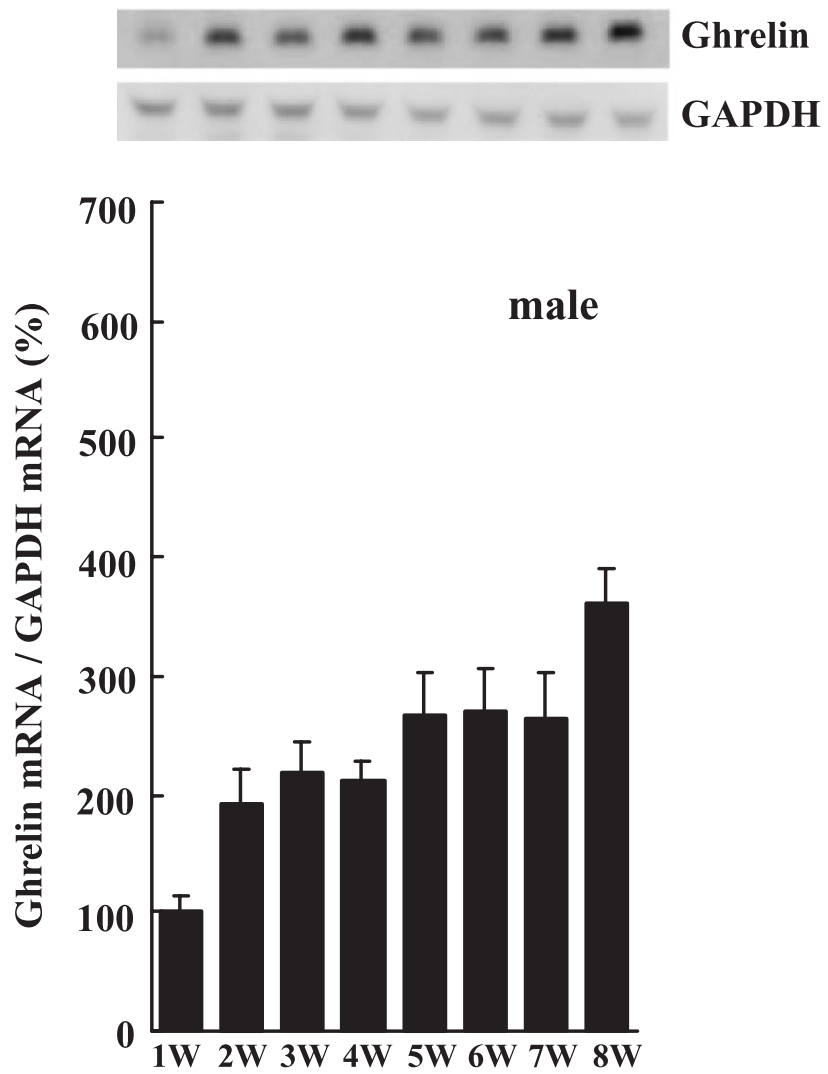

B
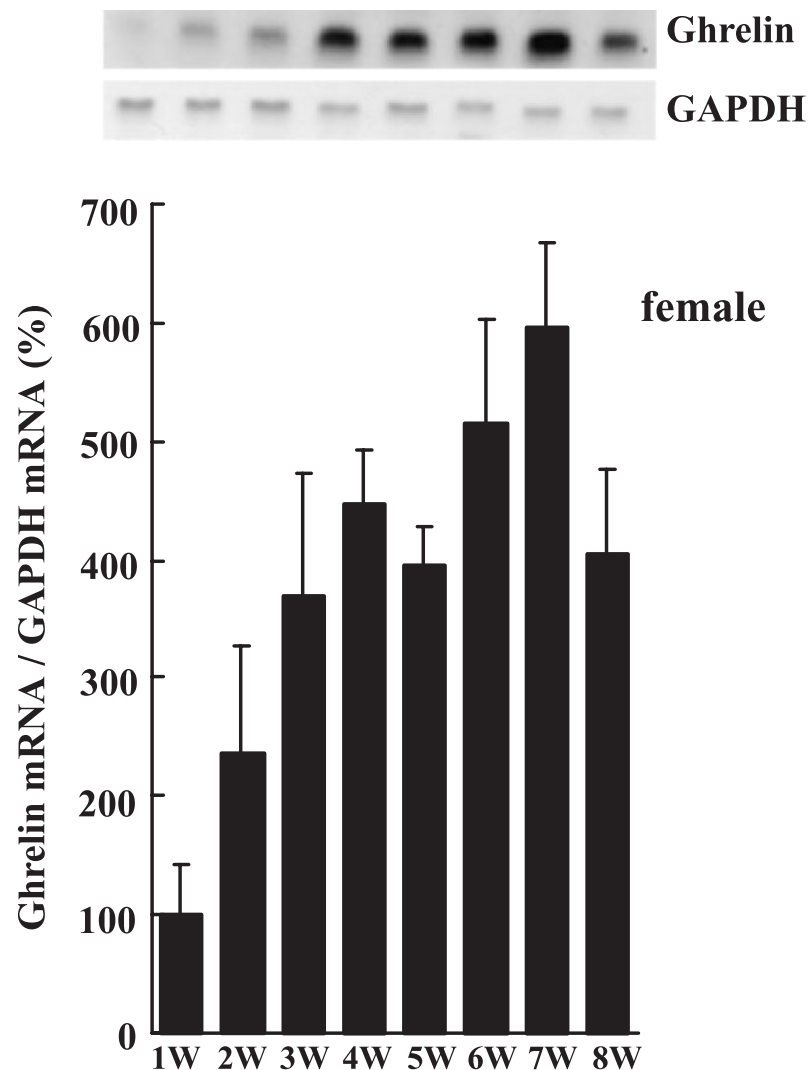

Figure 1 Changes in ghrelin mRNA levels during the postneonatal period in the rat stomach as determined by Northern blot analysis. The top panel shows representative results of Northern blot analysis of ghrelin and GAPDH mRNA in the rat stomach. The data in (A) and (B) are shown as the \% of 1 -week-old (1W) rats $(100 \%)$ and each bar represents the mean \pm S.E. $(n=3)$. (A) Ghrelin mRNA levels in male rats. Stomach ghrelin mRNA levels increased overall with age but showed transient stagnation at 4 weeks of age, and the amount of stomach ghrelin mRNA was highest at 8 weeks of age. (B) Ghrelin mRNA levels in female rats. As in the male rats, stomach ghrelin mRNA levels increased with increasing age but showed transient stagnation at 5 weeks of age. The amount of female stomach ghrelin mRNA peaked at 7 weeks of age and was lower at 8 weeks of age.

same localization in the stomach during all stages studied (up to 8 weeks of age). Ghrelin-ip and -ex cells were also found in the mucosal layer but not in the myenteric plexus. Ghrelin-ip and -ex cells were found just after birth in both sexes. The distributions of ghrelin-ip and -ex cells in the stomach changed: ghrelin cells were observed in the glandular base until 2 weeks of age (Figs $2 \mathrm{~A}$ and D and $3 \mathrm{~A}$ and $\mathrm{D})$ but were localized in the glandular base to the body of the fundic gland at 3 weeks of age (Fig. 2B and $\mathrm{E}$ and Fig. $3 \mathrm{~B}$ and $\mathrm{E}$ ). It is therefore thought that ghrelin-ip and -ex cells had spread with increasing age from the glandular base to the neck of the fundic gland (Fig. 2C and F and Fig. 3C and F). The ghrelin cell density in the male fundic gland showed an age-dependent increase after birth (Fig. 4), whereas the cell density in the female fundic gland remained almost constant during the period from 1 to 8 weeks after birth (Fig. 5). Moreover, cell densities in female rats were 2 - to $2 \cdot 5$-fold higher at 1 week after birth, and the densities of ghrelin-ip and -ex cells were found to be significantly higher in the female rats than in the male rats at least until 3 weeks of age (data not shown).

Two kinds of stained ghrelin-ex cells, weakly or strongly stained cells, were found in the female rats at the early stage of development (Fig. 3D and E). Interestingly, the ratios of these cells in the male and female rats were markedly different, and numerous weakly stained cells were prominent in the female rats (Fig. 3D and E). The existence ratio of these cells in the female rats decreased with growth, and few weakly stained ghrelin-ex cells were found at 7 weeks of age (Fig. 3F).

\section{Discussion}

It is generally accepted that $\mathrm{GH}$ release from somatotropes in the anterior pituitary gland is controlled by GHRH and 


\section{male}

\section{$\mathrm{IHC}$}
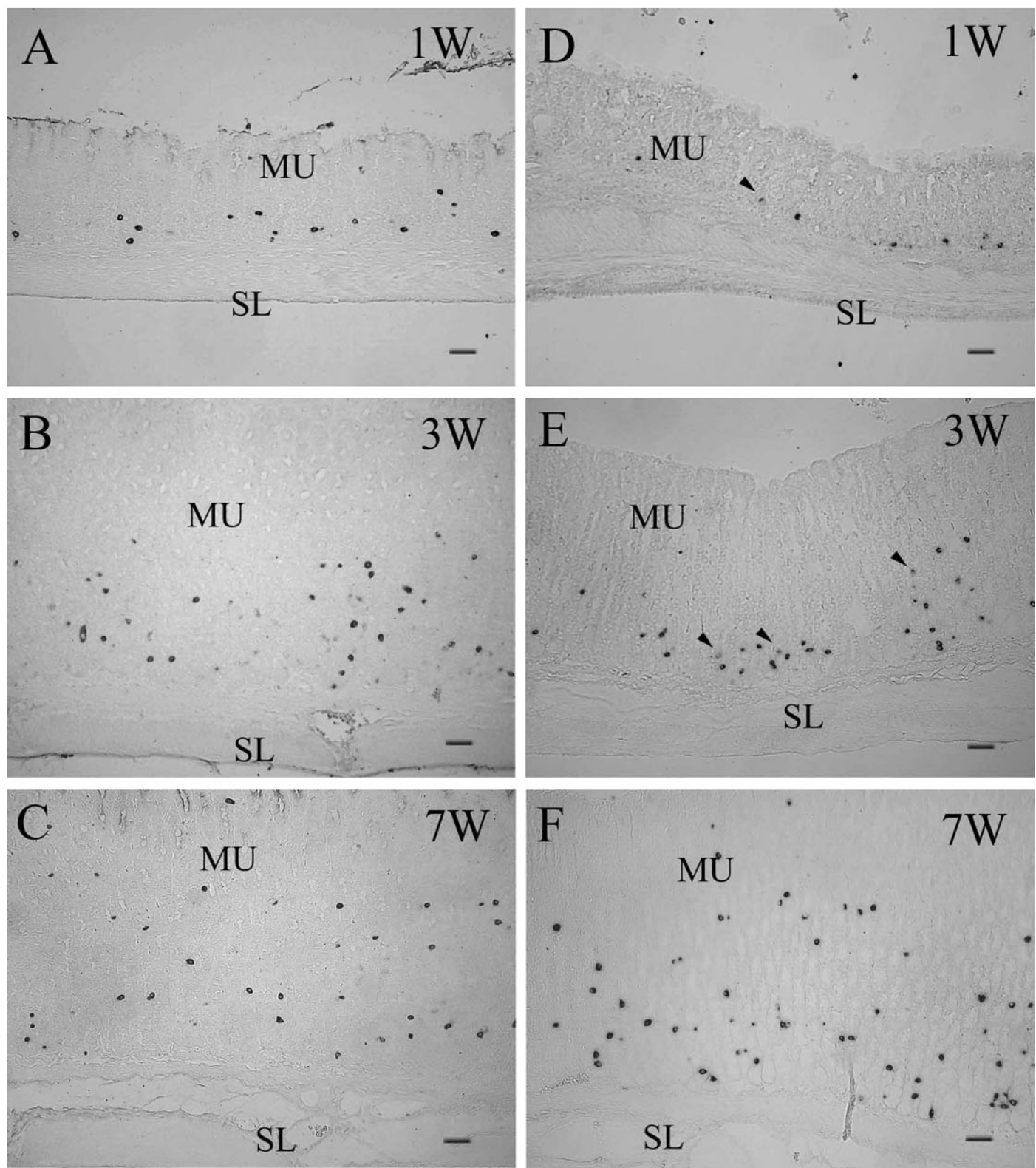

Figure 2 Microphotographs of ghrelin-ip and -ex cells in the male stomach. (A-C) Ghrelin-ip cells detected by IHC. (D-F) Ghrelin-ex cells detected by ISH. Ghrelin cells were found to be restricted to gastric mucosa. Almost all of the ghrelin cells in the stomach were round-shaped cells, so-called closed-type cells. The distribution of ghrelin-ip cells determined by IHC corresponds well to the distribution of ghrelin-ex cells. (A and D) A few ghrelin cells were found at 1 week (W) of age and were localized in the glandular base. (B and E) Many ghrelin cells were found at 3 weeks in the glandular base to the body of the fundic gland. ( $C$ and F) Many ghrelin cells were found at 7 weeks, and they had become scattered from the glandular base to the glandular neck. Although a few weakly stained cells (arrowheads) were found in the early stage ( $D$ and $E$ ), the staining signals in the cells remained almost constant throughout all stages of development. MU, mucosa; SL, smooth muscle layer. Bars $=100 \mu \mathrm{m}$. 


\section{female}

\section{$\mathrm{IHC}$}
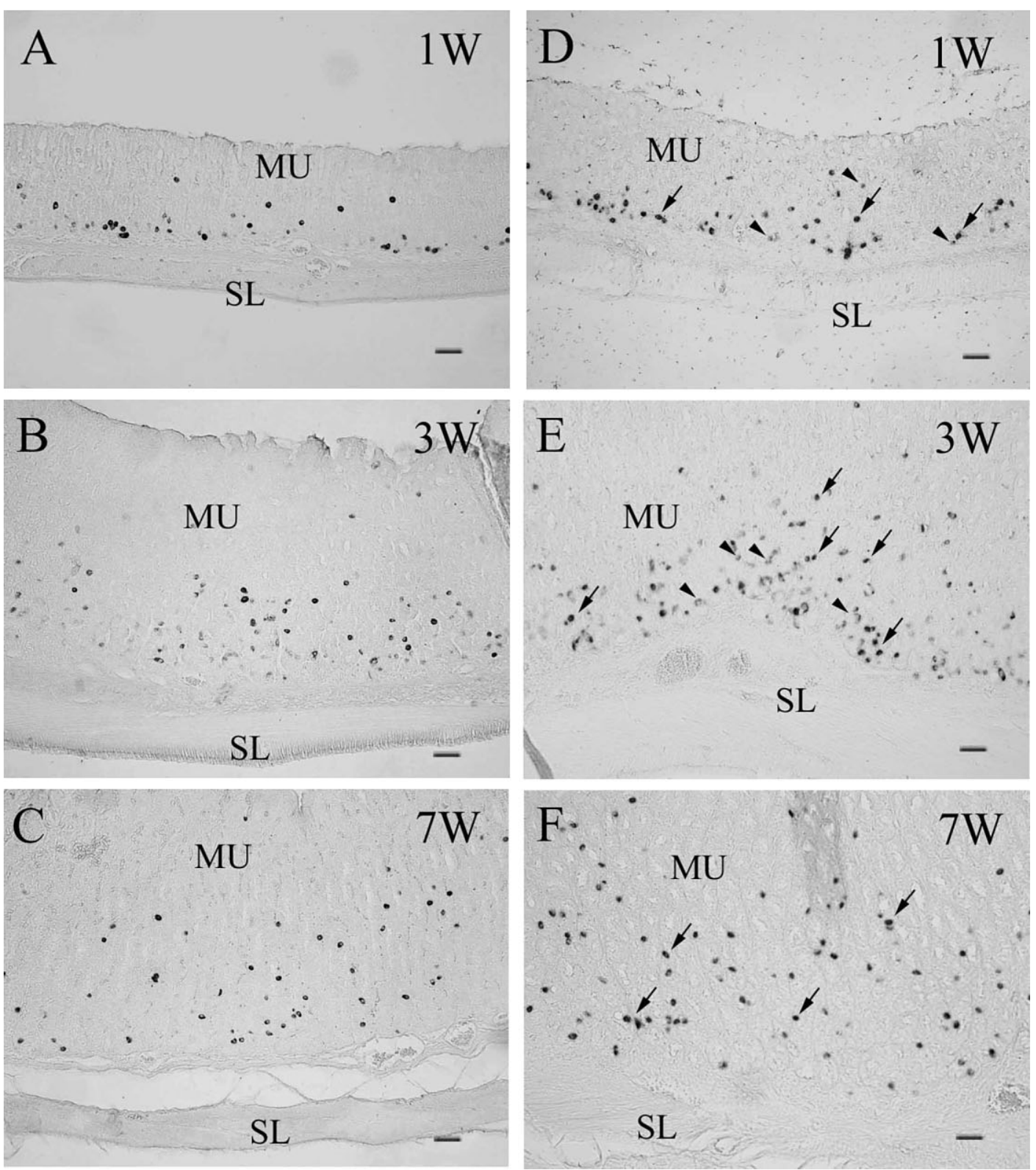

Figure 3 Microphotographs of ghrelin-ip and -ex cells in the female stomach. (A-C) Ghrelin-ip cells detected by IHC. (D-F) Ghrelin-ex cells detected by ISH. Distribution pattern of ghrelin cells and cell types are the same as those in the male, but the ghrelin-ip and -ex cells in the female stomach were more numerous than those in the male stomach at all stages. (A and D) Ghrelin -ip and -ex cells were found at 1 week (W) of age and were localized in the glandular base. Note that ghrelin -ip and -ex cells were more numerous than those in the male. (B and E) Ghrelin-ip and -ex cells were found in the glandular base to the body of the fundic gland at 3 weeks. (C and F) A large number of ghrelin cells were found at 7 weeks, and they were scattered through the glandular base to glandular neck. In the female, weakly stained cells (arrowheads) and strongly stained cells (arrows) were observed by ISH (D, E and F). The ISH signals at 1 and 3 weeks of age were shown to be a mixture of different staining intensities, but the staining in most of the cells at 7 weeks was strong (arrows). The ratio of weakly stained cells was higher in the female rats than in the male rats. $\mathrm{MU}$, mucosa; SL, smooth muscle layer. Bars $=100 \mu \mathrm{m}$. 


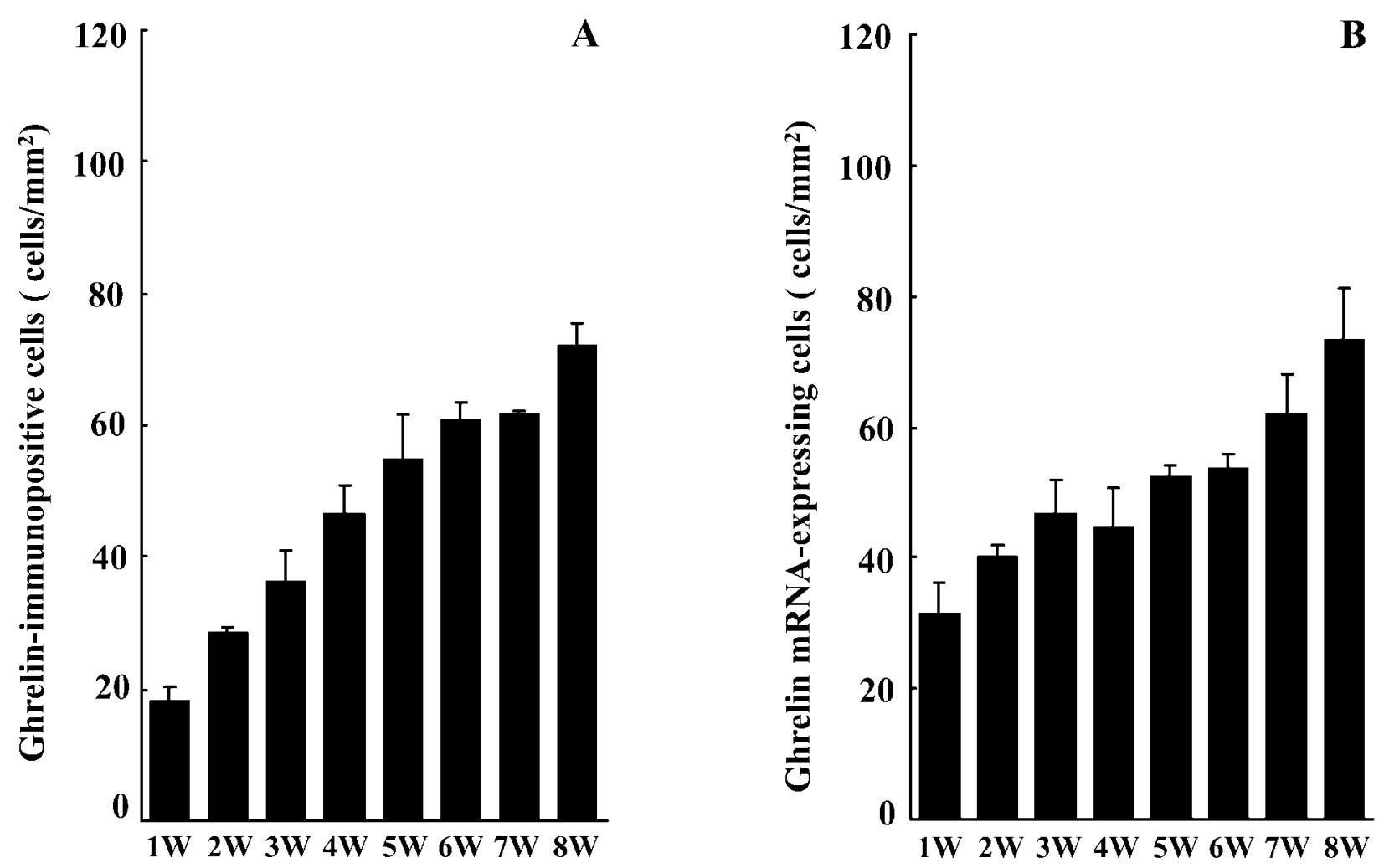

Figure 4 (A) Histogram showing the densities of ghrelin-ip cells $\left(\right.$ cells $/ \mathrm{mm}^{2}$ ) in the male stomach detected by IHC. The number of ghrelin-ip cells increased with age. (B) Histogram showing the densities of ghrelin-ex cells (cells $\left./ \mathrm{mm}^{2}\right)$ in the male stomach detected by ISH. The number of ghrelin gene-expressing cells increased with increasing age but showed transient stagnation at 4 weeks as shown by Northern blot analysis.

SRIF, and these neuropeptides are secreted from the hypothalamus and act on the anterior pituitary gland via the hypophysial portal vein. After the discovery of ghrelin, the mechanisms of $\mathrm{GH}$ release should be considered together with the inter-relationship between these peptides. However, among these peptides, ghrelin may have a complex effect on the pituitary gland because, although its content is significantly different from those of other peptides, sources of ghrelin have been reported in various regions, including the stomach, hypothalamus and the pituitary gland itself (Horvath et al. 2001). Ghrelin from these different sources may have an effect not only on GH release in adults but also on pituitary gland development. However, the source of ghrelin that is involved in $\mathrm{GH}$ release during the period of development has not been determined. Interestingly, the pattern of gastric ghrelin mRNA expression and differentiation of ghrelinproducing cells found in this study are significantly different from the previously reported pattern of pituitary ghrelin mRNA expression, i.e. ghrelin mRNA level in the pituitary gland being highest in the fetal stage then decreasing with increasing age (Kamegai et al. 2001). The gastric ghrelin mRNA levels in the present study showed a completely opposite pattern; lowest just after birth and increasing with increasing age. On the other hand, it has been reported that the pituitary GHS-R mRNA expression level was significantly higher just after birth and at 4-5 weeks of age (Kamegai et al. 1999), and the periods of these two peaks are consistent with the increases in pituitary and gastric ghrelin expression levels respectively. Taken together, these results suggest that GH secretion from somatotropes is controlled by ghrelin from different origins in the various stages of development.

It has been reported that plasma acylated ghrelin is very unstable (Ariyasu et al. 2001). In addition, ghrelin from the stomach may be degraded rapidly by passing from the portal vein to the liver. Therefore, it is questionable whether or not gastric ghrelin directly stimulates $\mathrm{GH}$ release from the pituitary gland via physiologically active plasma ghrelin. Moreover, the results of our study using a perifusion system demonstrated that GHRH stimulates $\mathrm{GH}$ release from the anterior pituitary gland more strongly (about ten times more strongly) than does ghrelin (Yamazaki et al. 2002). These results suggest that gastric ghrelin in the adult does not directly stimulate somatotropes but has an effect on $\mathrm{GH}$ release by an 


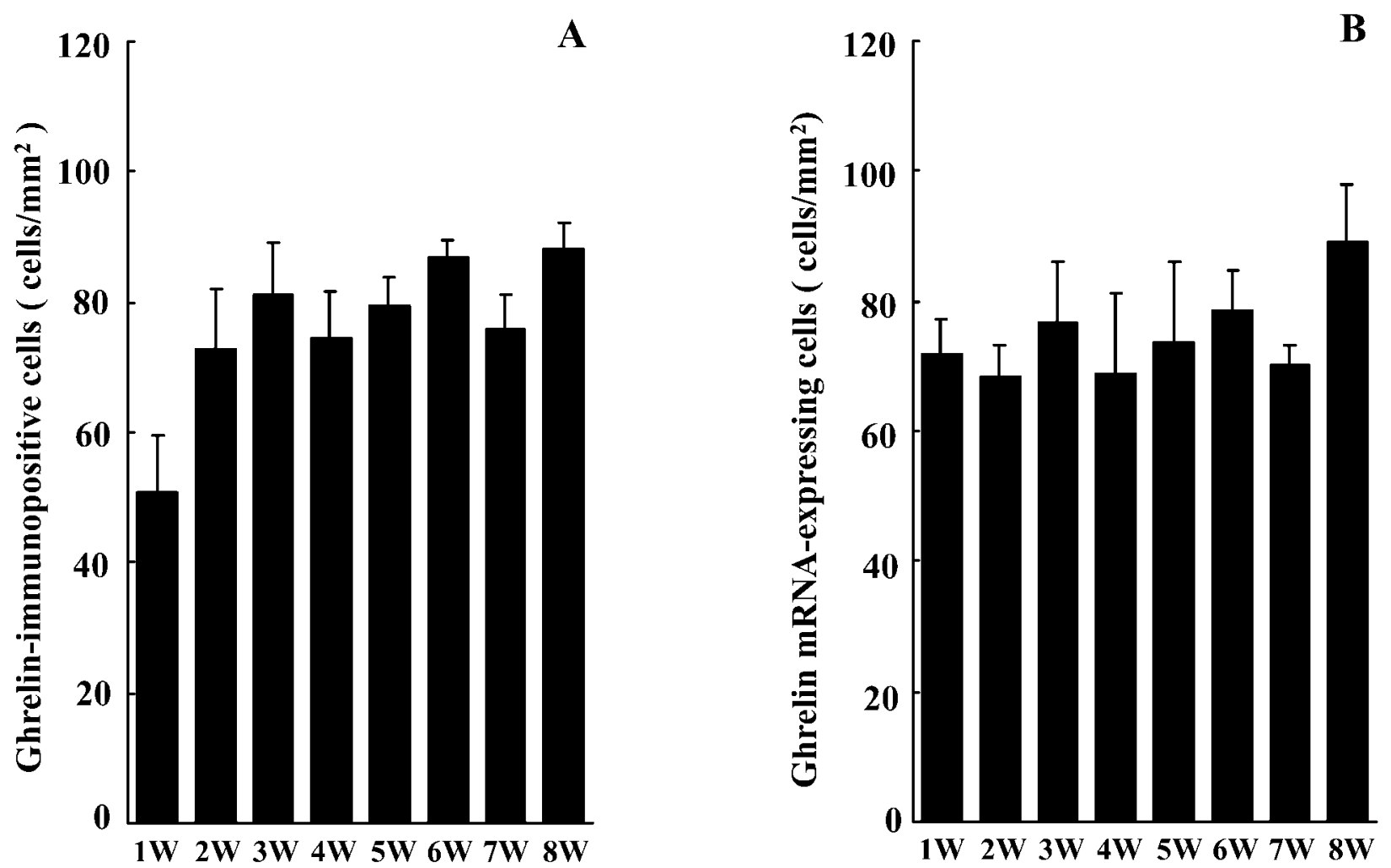

Figure 5 (A) Histogram showing the densities of ghrelin-ip cells $\left(\right.$ cells $/ \mathrm{mm}^{2}$ ) in the female stomach detected by IHC. The number of ghrelin-ip cells increased rapidly from 1 to 2 weeks of age and then became almost constant. (B) Histogram showing the densities of ghrelin-ex cells (cells $/ \mathrm{mm}^{2}$ ) in the female stomach detected by ISH. The density of ghrelin cells remained almost constant throughout the period of development. Note that the densities of ghrelin cells in the female rat were higher than those in the male rats at all stages (compare with Fig. 4).

indirect route. Recently, many studies have demonstrated that ghrelin also regulates food intake, gastric acid secretion and gastric motor activity via vagal control systems (Masuda et al. 2000, Asakawa et al. 2001a, Date et al. 2001). Considering these findings, it is not surprising that plasma ghrelin stimulates $\mathrm{GH}$ secretion via the vagal nerve and has indirect effects through neural pathways. Elucidation of the sites of action of stomach ghrelin and changes in stomach ghrelin during development may be needed to understand the physiological role of ghrelin.

Recently, several studies have demonstrated ontogeny of stomach ghrelin gene expression. For example, Tanaka et al. (2001) reported that no significant changes in the amount of ghrelin mRNA in the mouse stomach was observed during the period 2-8 weeks after birth. On the other hand, Lee et al. (2002) reported that rat gastric ghrelin mRNA increased progressively through the second and third weeks after birth and that the ghrelin mRNA level in the stomach thereafter remained constant until the end of the nursing period. In addition, Gualillo et al. (2001) reported that gastric ghrelin gene expression in the rat increased with increasing age (up to 90 days). In this study, we found that ghrelin gene expression increased in a stepwise manner, a finding that is almost in agreement with the results of the latter two reports mentioned above. Notably, although their study was not continued after 23 days of age, Lee et al. (2002) reported that rat ghrelin gene expression peaked at 18 days of age and then decreased until 22 days of age. This change in gene expression is in good accordance with that of the first peak of our results. Although further studies are needed to elucidate the physiological significance of ghrelin mRNA fluctuation, it should be pointed out that the first increase in the expression level is closely related to the weaning period or rapid body growth period. Moreover, this period is almost consistent with the onset of puberty.

In the male rats, the densities of ghrelin-ip and -ex cells increased gradually, and the increase paralleled that in ghrelin mRNA expression level. On the other hand, in the female rat stomach, although numerous ghrelin-ex cells were found in neonates and cell densities remained almost constant throughout development, ghrelin mRNA expression showed a stepwise increase, suggesting that changes in ghrelin gene expression did not reflect the 
morphological results. For this reason, since we counted ghrelin-ex cells without taking into consideration the staining intensity in this study, even weakly stained cells were considered as ghrelin gene-expressing cells. However, as pointed out in the Results section, many weak signals were found by ISH in the female rats, and these cells were replaced with strongly stained cells with the advance of the process of development, indicating that the ghrelin mRNA expression level increases after birth. These results suggest that ghrelin-producing cells in female rats differentiate at an earlier stage of development than they do in male rats. The difference between the stages of development at which ghrelin-producing cells differentiate in male and female rat stomachs is a very interesting issue, and this difference suggests that ghrelin has distinct physiological effects on male and female development.

\section{Acknowledgements}

We are grateful to $\mathrm{K}$ Inoue $\mathrm{PhD}$ and $\mathrm{K}$ Nakamura MS (Saitama University, Faculty of Science, Saitama, Japan) for their valuable discussion and technical suggestions.

\section{References}

Argente J, Chowen JA, Zeitler P, Clifton DK \& Steiner RA 1991 Sexual dimorphism of growth hormone-releasing hormone and somatostatin gene expression in the hypothalamus of the rat during development. Endocrinology 128 2369-2375.

Ariyasu H, Takaya K, Tagami T, Ogawa Y, Hosoda K, Akamizu T, Suda M, Koh T, Natsui K, Toyooka S, Shirakami G, Usui T, Shimatsu A, Doi K, Hosoda H, Kojima M, Kangawa K \& Nakao K 2001 Stomach is a major source of circulating ghrelin, and feeding state determines plasma ghrelin-like immunoreactivity levels in humans. Journal of Clinical Endocrinology and Metabolism 86 $4753-4758$.

Asakawa A, Inui A, Kaga T, Yuzuriha H, Nagata T, Ueno N, Makino S, Fujimiya M, Niijima A, Fujino MA \& Kasuga M 2001a Ghrelin is an appetite-stimulatory signal from stomach with structural resemblance to motilin. Gastroenterology 120 337-345.

Asakawa A, Inui A, Kaga T, Yuzuriha H, Nagata T, Fujimiya M, Katsuura G, Makino S, Fujino MA \& Kasuga M $2001 b$ A role of ghrelin in neuroendocrine and behavioral responses to stress in mice. Neuroendocrinology 74 143-147.

Date Y, Murakami N, Kojima M, Kuroiwa T, Matsukura S, Kangawa K \& Nakazato M 2000 Central effects of a novel acylated peptide, ghrelin, on growth hormone release in rats. Biochemical and Biophysical Research Communications 275 477-480.

Date Y, Nakazato M, Murakami N, Kojima M, Kangawa K \& Matsukura S 2001 Ghrelin acts in the central nervous system to stimulate gastric acid secretion. Biochemical and Biophysical Research Communications 280 904-907.

Eden S 1979 Age- and sex-related differences in episodic growth hormone secretion in the rat. Endocrinology 105 555-560.

Gualillo O, Caminos JE, Kojima M, Kangawa K, Arvat E, Ghigo E, Casanueva FF \& Dieguez C 2001 Gender and gonadal influences on ghrelin mRNA levels in rat stomach. European Journal of Endocrinology 144 687-690.

Horvath TL, Diano S, Sotonyi P, Heiman M \& Tschop M 2001 Minireview: ghrelin and the regulation of energy balance - a hypothalamic perspective. Endocrinology 142 4163-4169.
Hosoda H, Kojima M, Matsuo H \& Kangawa K 2000a Ghrelin and des-acyl ghrelin: two major forms of rat ghrelin peptide in gastrointestinal tissue. Biochemical and Biophysical Research Communications 279 909-913.

Hosoda H, Kojima M, Matsuo H \& Kangawa K 2000b Purification and characterization of rat des-Gln14-Ghrelin, a second endogenous ligand for the growth hormone secretagogue receptor. Journal of Biological Chemistry 275 21995-22000.

Inui A 2001 Ghrelin: an orexigenic and somatotrophic signal from the stomach. Nature Reviews. Neuroscience 2 551-560.

Kamegai J, Wakabayashi I, Kineman RD \& Frohman LA 1999 Growth hormone-releasing hormone receptor (GHRH-R) and growth hormone secretagogue receptor (GHS-R) mRNA levels during postnatal development in male and female rats. Journal of Neuroendocrinology 11 299-306.

Kamegai J, Tamura H, Shimizu T, Ishii S, Sugihara H \& Oikawa S 2001 Regulation of the ghrelin gene: growth hormone-releasing hormone upregulates ghrelin mRNA in the pituitary. Endocrinology 142 4154-4157.

Kojima M, Hosoda H, Date Y, Nakazato M, Matsuo H \& Kangawa K 1999 Ghrelin is a growth hormone-releasing acylated peptide from stomach. Nature 402 656-660.

Lee HM, Wang G, Englander EW, Kojima M \& Greeley GH Jr 2002 Ghrelin, a new gastrointestinal endocrine peptide that stimulates insulin secretion: enteric distribution, ontogeny, influence of endocrine, and dietary manipulations. Endocrinology 143 185-190.

Masuda Y, Tanaka T, Inomata N, Ohnuma N, Tanaka S, Itoh Z, Hosoda H, Kojima M \& Kangawa K 2000 Ghrelin stimulates gastric acid secretion and motility in rats. Biochemical and Biophysical Research Communications 276 905-908.

Nakazato M, Murakami N, Date Y, Kojima M, Matsuo H, Kangawa K \& Matsukura S 2001 A role for ghrelin in the central regulation of feeding. Nature 409 194-198.

Sakai T, Satoh M, Koyama H, Iseki K, Umahara M, Fujikura K \& Ito Z 1994 Localization of motilin-immunopositive cells in the rat intestine by light microscopic immunocytochemistry. Peptides $\mathbf{1 5}$ 987-991.

Sakata I, Nakamura K, Yamazaki M, Matsubara M, Hayashi Y, Kangawa K \& Sakai T 2002 Ghrelin-producing cells exist as two types of cells, closed- and opened-type cells, in the rat gastrointestinal tract. Peptides 23 531-536.

Seoane LM, Tovar S, Baldelli R, Arvat E, Ghigo E, Casanueva FF \& Diequez C 2000 Ghrelin elicits a marked stimulatory effect on GH secretion in freely-moving rats. European Journal of Endocrinology 143 R7-R9.

Tanaka M, Hayashida Y, Nakao N, Nakai N \& Nakashima K 2001 Testis-specific and developmentally induced expression of a ghrelin gene-derived transcript that encodes a novel polypeptide in the mouse. Biochimica et Biophysica Acta 1522 62-65.

Toshinai K, Mondal MS, Nakazato M, Date Y, Murakami N, Kojima M, Kangawa K \& Matsukura S 2001 Upregulation of Ghrelin expression in the stomach upon fasting, insulin-induced hypoglycemia, and leptin administration. Biochemical and Biophysical Research Communications 281 1220-1225.

Wren AM, Small CJ, Ward HL, Murphy KG, Dakin CL, Taheri S, Kennedy AR, Roberts GH, Morgan DGA, Ghatei MA \& Bloom SR 2000 The novel hypothalamic peptide ghrelin stimulates food intake and growth hormone secretion. Endocrinology 141 4325-4328.

Yamazaki M, Nakamura K, Kobayashi H, Matsubara M, Hayashi Y, Kangawa K \& Sakai T 2002 Regulational effect of ghrelin on growth hormone secretion from perifused rat anterior pituitary cells. Journal of Neuroendocrinology 14 156-162.

Received in final form 10 May 2002 Accepted 14 May 2002 